\title{
LETTER TO N. H. BAYNES
}

From HUGH LAST

\author{
Brasenose College, \\ Oxford. \\ I 8 November 1946 .
}

\section{Dear Baynes,}

I am de trop. My part in this tribute was to provide the packing-a concertina-article to fill such space as was left when others had said their says. As it is, they have filled it all : so, if I did my duty, I should just disappear. But on this occasion I am going to defaultso far as not to leave myself out altogether; for I should be sad to be missing from your well-wishers when the vehicle of their greetings is $\mathcal{F R S}$. Still I must be brief; and for brevity I am going to write not an article but a letter-and that not unwillingly, because in a letter it is easier to do at least one thing I should like. That is to say my 'thank you'. It is well over a quarter of a century ago that our friendship started that evening when we met here as guests of Stuart Jones. Since then our correspondence has been such that a fortnight's break seems a long interruption; and often there have been 'fusilades'. To me, as to very many others whose work lies in one of the various fields of which you are master, your letters have been one of the most wholly satisfactory features of life. For them thus far, and for the help you give so freely to every scholar, young or old, who asks, I want to put my gratitude on record-which now hereby I do.

Next, business ; and I hope of the kind we both enjoy-skirmishing a bit ahead. First a word about Seeck. You and I both hold that great man in higher regard than he got from some of his fellow Germans; but I grow more and more uncertain whether we have not done him an injustice about the 'Ausrottung'. And, quite apart from any question of fairness, or even of the decline in the West, the matter itself is important enough, goodness knows : one doesn't need to have made study of the NSDAP one's war-work for recent

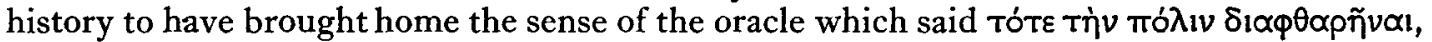

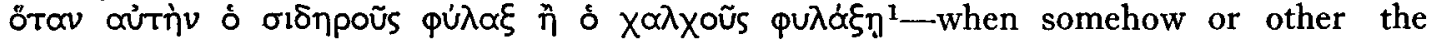
$\chi p \cup \sigma \circ \tilde{I}$ have been displaced, when there has been a process which, whatever its precise nature, has produced the same results as an 'Ausrottung der Besten '. (Don't take any notice of the catch-numbers. They refer to some notes I'm adding-at the end-because this is going to be printed.)

Of course Seeck's case won't do as it stands, even if one remembers that he put the start of the liquidation of capacity a long way back, in the time of Tiberius Gracchus, ${ }^{2}$ and that he seems to have been thinking of the Julio-Claudians when he said the emperors became wolves because their subjects were sheep. ${ }^{3}$ And I don't think that much good is done by pushing back the start still farther, as Toynbee does, ${ }^{4}$ to the Peloponnesian Warplausibly perhaps if one believes in a single 'Hellenic Society', as personally I do not, for reasons given by Collingwood. ${ }^{5}$ These people certainly get near a valuable truth ; but $I$ fancy that they miss it-by assuming that if the best are exterminated it must be mainly, if not wholly, by murder and sudden death.

One of Seeck's merits was that, so far as seemed relevant to his job, he tried to keep abreast of the science of his day : look at the notes in Untergang $1^{4}, 548 \mathrm{ff}$. But in that day biology was still Darwinian: 'die Ausrottung der Besten' was first published (after some preliminary studies) in $\mathbf{1 8 9 5}$, five years before the date generally agreed to mark the rediscovery of Mendel's doctrines-and the final acceptance of Mendelism has made a lot of difference. In Darwinism heredity took the form of a blending in the offspring of the 
qualities of the parents-tall father, short mother, child of medium height. Yet somehow extremes of height have not been ironed out into uniform mediocrity. Mendelism, on the other hand, drops the blending hypothesis. The many qualities of the parents are a number of distinct units, some of which may be found complete in the next generation, others not at all-some are dominant, others recessive : the child of a very tall father and a very short mother is more likely to be either very tall or very short than of middling height.

So much is familiar; but it isn't all. When I was beginning my brief and breezy connection with the Clarendon Press, one of the books I read to find out what had been happening on the scientific side was R. A. Fisher's Genetical Theory of Natural Selection ; ${ }^{6}$ and that work contains suggestions (which I gather not to have been refuted), with some bearing on history in general and on Seeck in particular. Briefly the story is that Francis Galton, having noticed that marriages between peers (or their sons) and heiresses tended to produce abnormally small numbers of children, was led to suspect that an heiress, the sole issue of a marriage, was likely to be less fertile than a woman with many brothers and sisters. The result was his conjecture that ' comparative infertility' (by which he means a tendency in those who marry to have few children), ' must be hereditary in the same way as other physical attributes '.? That conjecture seems to have been completely confirmed, and what Fisher does is to draw out its sociological consequences. His point is that, if this comparative infertility is capable of hereditary transmission, then, wherever the wealth of parents, even if on their death it is equally divided among the children, has to provide for their education and at least helps to establish them in the position they will occupy in life, stocks comparatively infertile have a social advantage over the comparatively fertile. For in any society in which wealth plays a considerable part in determining social status the relatively infertile tend to come to the top, because in individuals of that class wealth is more highly concentrated than in members of more prolific stocks. So, in any such society, a relatively infertile stock has the best chance of social advancement, and there is a natural process tending to the social promotion of low fertility.

But when the comparatively infertile come to the top their eminence is fleeting, because low fertility is not a quality which a stock can long retain. Either its fertility is stepped up, or it dies out. On this subject there is a passage in Galton which shouts an invitation to inquiry about its possible relevance to some periods of Roman history. He is dealing with evidence got from Foss's fudges of England ${ }^{8}$ (which does not include the Judges of the Court of Admiralty or of the Court of Canterbury). There he finds that the Judges who last sat on the bench between 1660 and 1830 and were raised to the peerage, and whose mother was, or who, or whose sons, married, an heiress or a co-heiress were seventeen in all, and that among them ' the direct male line of no less than eight peerages, viz. Colpepper, Harcourt, Northington, Clarendon, Jeffreys, Raymond, Trevor, and Rosslyn were (sic) actually extinguished through the influence of the heiresses, and that six others, viz. Shaftesbury, Cowper, Guilford, Parker, Camden, and Talbot, had very narrow escapes from extinction, owing to the same cause ' .9 So much for the biological consequence of comparative infertility-the quality which where wealth is a means to social advancement brings stocks to the top of the social scale.

The extinction of families is due of course to different causes in different cases. If this disposition to relative infertility is one, it is only one of several, among which restriction of births by artificial means is another and violence a third. But if it turned out that comparative infertility at least in certain periods worked in the way which Fisher describes, should we not rather thank Seeck for a valuable hint than brush his theory aside because his statement of it needs elaboration? We may indeed have to say that the causes he offers for the 'Ausrottung', like the drain to the Church which also impressed him, as later it has impressed Momigliano, ${ }^{10}$ were not causes which started a process that did not begin till they occurred but merely causes of an acceleration in one which had been going on since certain economic conditions came into being. But, when all the qualifications have been made, I still think that on this point Seeck (to whom here I say good-bye) deserves well. For, even if there were no truth in the theory that an economic system in which wealth 
gives status tends to produce the social advancement of stocks biologically feeble or even moribund, it would still be a fact that in recorded history the disappearance of leading families is often striking.

Figures of the number of patricians in the Senate at various times during the Republic can mislead ; for their decrease, apart from transitions to the plebs, was partly due to poverty having forced out of public life families of the sort which Sulla and Iulius brought into it again. But in the later Republic and the Principate there is a tendency among leading houses to die out clear enough, even when one makes allowance for the later spread of birth restriction, to make plausible the evidence which suggests that, whatever the causes, this form of wastage had been going on at Rome a long way back in the Republic. And one can use the pronouncement of Metellus Macedonicus in 13I/o B.c. ${ }^{11}$ as a clue to the latest date by which some people had begun to think seriously about the birth-rate. So there was a problem-why there was this wastage ; and its existence justifies the attempts to solve it made at intervals since Niebuhr suggested epidemics as the earliest cause. ${ }^{12}$ By now it is plain that the cause was complex. One element was voluntary limitation of families; battle and murder were others; but to them natural infertility in high places may have to be added.

This prompts a word about prosopography. The prosopographers are certainly opening a way forward, but it may not lead as far as it might until they take systematic account of such facts as survive about the productivity of at least the more interesting stocks. Evidence of this sort only tells in bulk; but, for what little it is worth, one may give a single illustration. So far as we know, Iulius the Dictator had two sisters. His first wife had one sister, and one brother (or perhaps two) ; and she bore him a child. His second and third wives, however, each had only one recorded brother, and both these marriages seem to have been barren. Kleopatra VII, for whose fertility there is plenty of evidence, is said to have been one of four children of Auletes still alive when their father died. ${ }^{13}$ Then Augustus : he had only one full sister.

But there is another, and more important, aspect of this business, which also concerns the prosopographers. If for whatever reasons leading families were apt to die out, it becomes a question who were found to take their places. The issue about the recruitment of the governing class runs all through the history of the Republic and a very long way into the Empire. The Struggle of the Orders, in one of its aspects, was an attempt-superficially successful-by those outside this class to make access to it free; but, when the plebs had got into every office that mattered, the new nobilitas soon became as exclusive as ever the old patriciate had been. The citadel of their position was the consulship, from which noui homines were to be kept out by all possible means (which I suppose is why they were so angry with $\mathrm{Ti}$. Gracchus for threatening to turn their position by substituting the tribunate as the most important office in Rome); but in the end they were routed. Men born outside the oligarchy might aspire to any position, even that of Princeps, and the old claim of the populares was finally established-that the title to advancement was to be not birth but ability.

So much needs no argument. But then comes another question-what sort of ability ? And not merely ability. Thanks to the prosopographers we are beginning to know when and in what numbers municipal Italians and provincials were recruited to the Senate. But to say that a man came from here or there is not enough. We want to find out, if we can, something about the qualities he brought with him-not of course about all his qualities, but about those which would affect the character of a government or an administration in which he had a share of the responsibility.

You remember the publication of Graham Wallas's Human Nature in Politics. ${ }^{14}$ Probably it impressed me more than it did you, because I was still a schoolboy and you by then knew the Republic; but I shan't forget my own excitement at being invited to admit that man is not a wholly rational animal, that his conduct is strongly influenced by sentiment, and that some notorious parts of the political philosophy of the nineteenth century rested on assumptions not all of which were sound. When my turn came to read the Republic, Wallas made me see more of value than some of the commentators would suggest 
in what Plato tries to express, not perhaps quite adequately, in his conception of to

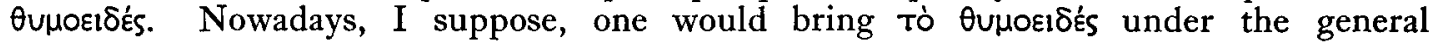
head of sentiment, which covers much; but the form of sentiment which makes men stand

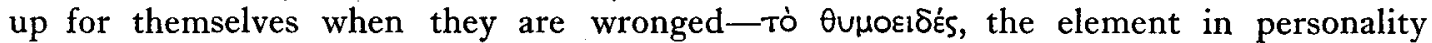

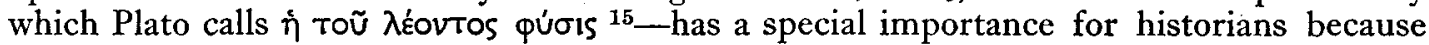
this is at least one of the qualities in their leaders and their citizens which give strength to States. In times of stress the leadership of a Churchill does make a difference (think of the Illyrians or of Heraclius) - if he has behind him a people enough like himself to rise to his inspiration; and not in times of stress alone.

The members of every society are naturally divided into what briefly one may call a governing class and a governed; and for a good many purposes these have to be treated separately. About the governing class one thing of importance is the nature of its dominant sentiments. Are its members mainly of the sort, for instance, which is inclined to depend on its wits (not necessarily for its own private advantage alone) and, if that can be anyhow managed, avoid recourse to policies which run a risk of war; or of the sort which sticks to its principles, goes ahead, and is ready to fight when attacked ? If it be true that a governing class is always shedding some of the stocks which have belonged to it in the past and incorporating new, it is worth while to find out something about the outlook and character of the recruits. No one, I imagine, would deny that, if the rise of Sosibius under Ptolemy IV was not a good thing, that of Eulaeus and Lenaeus under Ptolemy VI was much worse, and that of Agrippa and his like under Augustus was far better than either. And then there are the governed : they matter quite as much, because leadership however good is useless if the people do not respond when the crisis comes. About them and their sentiments we need the same kind of information-if we can get it, as I think in ancient history perhaps we can, at any rate to an extent that would justify the attempt. Something has been done here and there in this direction already : A. Bayet for instance has at least glanced at this side of the history of Gaul; ${ }^{16}$ Alföldi has called attention to the value of the enlistment in the imperial service of what one may label the ' uirtus Illyrici '; 17 and I remember some relevant remarks of Ernst Stein's about the effects of military settlements, partly perhaps due to your friend Heraclius, on the morale of the people of the vital Asia Minor. ${ }^{18}$ But up till now historians, so far as I know, have scarcely dealt with these things more than obiter. And has there been any attempt at all (except for stray studies of Virgil, Livy, and the great Cisalpines of Flavian times) to tackle this aspect of the Republic and the Early Empire?

How such an attempt to trace the history of sentiment should be organized is a problem; for in dealing with the evidence one only gets into a muddle without some scheme for classifying the results. One such scheme is more or less familiar-that of V. Pareto in his Trattato di sociologia generale ${ }^{19}$ : fairly obviously it is not perfect, and certainly for historians whose information is as scanty as ours something simpler would be more useful. Unfortunately Pareto's history was not his strongest point : probably you have been shocked by the pronouncements about Byzantium with which he ends-and poor stuff they are. But his classification of sentiments is at least an approximation to what we need; and perhaps one may be pardoned for using it just once. So let me end with a statement and a question. East Rome-surprisingly, in view of the discomfort in which life was often livedwas a paradise of 'class II residues'. Why? What was it that made peoples of that Empire behave as men who might say ' we shall fight on the beaches, we shall fight in the fields and in the streets, we shall fight in the hills ; we shall never surrender ', and mean it ? If that question could really be answered, some of us at least would understand Byzantium far better than we do at present. And I suspect that, if it can be done at all, you are one who could show the way better than most; for it may be that the popular literature you know so well is more relevant to this business than the chronicles and the official stuff.

And now-please don't rebuke me for trying to saddle you with yet another task. Anyhow I have done it wilfully. You remember a book that moved us both in which the author hopes to escape " the last humiliation of an aged scholar, when his juniors conspire to print a volume of essays and offer it to him as a sign that they now consider 
him senile'20 - a description too often true. But here it is not : if it were, I should not be of this party. It is because I know you not to be aged that I haven't hesitated to ask you a very difficult question. And that you may be able to add at least some part of the answer to the many fresh services your friends count on you to render, let me join them in

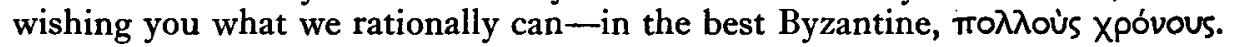

\section{Yours as always \\ Hugh Last.}

1 Plato, Rep. 3, 415 c.

2 Geschichte des Untergangs der antiken Welt $\mathbf{1}^{4}$ (Stuttgart, I92I), 285, 31 ff.

3 Ibid. 289 , 19 f.

4 A Study of History 4 (Oxford, 1939), 62.

5 The Idea of History (Oxford, 1946), $162 \mathrm{ff}$.

6 Oxford, I930.

7 F. Galton, Hereditary Genius (London, I 869), 132 (ed. 2, London, I892, 125 ).

8 E. Foss, The Fudges of England, 9 vols. (London, I 848-1 864).

9 o.c. in note 7,135 (ed. 2,128 ).

10 Enciclopedia italiana 29 (Rome, 1936), 637, and

- La formaizone della moderna storiografia sull' impero romano' in Rivista storica italiana, Ser. v, vol. i, 1936, fasc. i, 34-6o; fasc. ii, 19-48 (reprinted separately, Paravia, n.d.- ? I938), passim.

11 Livy, Per. 59 ; Suet. Diu. Aug. 89, 2 ; Gellius, $N A$ I, 6, I ff. (where 'Numidici' is wrong).

12 Römische Geschichte I, page of note 632 (The
History of Rome, translated by J. C. Hare and C. Thirlwall, $2^{3}$, London, 1838,278 ).

${ }_{13}$ Strabo 17, $796 \mathrm{C}$.

14 London, 1908 (ed. 3, 1920).

15 Rep. 9, 589 b.

${ }^{16}$ La morale païenne à l'époque gallo-romaine (Paris, I93I), esp. ch. xIV.

17 'Die Vorherrschaft der Pannonier im Römerreiche und die Reaktion des Hellenentums unter Gallienus,' in Fünfundzwanzig fahre römisch-germamsche Kommission (Berlin-Leipzig, 1930), I I-51, at $15 \mathrm{ff}$.

18 Studien zur Geschichte des byzantinischen Reiches (Stuttgart, 1919), I $32 \mathrm{ff}$.

192 vols. Florence, 1916 (ed. 2, 1923 ; translated into English by A. Bongiorno and A. Livingston as The Mind and Society, 4 vols., London, 1935).

20 R. G. Collingwood, An Autobiography (Oxto1d, 1939), 119. 